\title{
A salt, detergent, and solvent tolerant protease from Bacillus sp. B001: Low-cost, easy-purified, and enhanced production by raw material based culture strategy
}

\author{
Jie Wu ${ }^{1,2}$, Aihua Deng ${ }^{1}$, Nana Shi ${ }^{1}$, Shuwen Liu ${ }^{1}$, Yong Liang ${ }^{1}$, Tingyi Wen ${ }^{1 *}$ \\ ${ }^{1}$ CAS Key Laboratory of Microbial Physiological and Metabolic Engineering, Institute of Microbiology, Chinese Academy of Sci- \\ ences, Beijing, China \\ ${ }^{2}$ University of Chinese Academy of Sciences, Beijing, China \\ Email: *wenty@im.ac.cn
}

Received 4 September 2013; revised 15 October 2013; accepted 12 November 2013

Copyright (C) 2013 Jie Wu et al. This is an open access article distributed under the Creative Commons Attribution License, which permits unrestricted use, distribution, and reproduction in any medium, provided the original work is properly cited.

\begin{abstract}
To enhance the protease production and decrease cost, corn flour and soy peptone were screened as cheap raw materials for the production of extracellular proteases by Bacillus strains. Their compositions in the medium suitable for enzyme production of Bacillus sp. B001 were optimized using statistical experiment designs. Under the optimized conditions, the protease production of Bacillus sp. B001 was stable at the stationary stage and reached to $63,200 \mathrm{U} / \mathrm{mL}$, approximately 1.84-fold increase compared with that using the original medium. These improvements could be attributed to the release of the catabolite repression by crude materials corn flour and soy peptone which contained low level of available nutrients. Additionally, a highly pure protease which displayed excellent stability and compatibility with high salinity, commercial laundry detergents, and organic solvents, was rapidly obtained by two-step procedure involving ammonium sulphate precipitation and anion exchange from the fermentation cultures of B001 in the optimized medium. When the culture method applied to other Bacillus strains, their protease yields were all remarkably increased approximately 2.9 to 8.5 folds. In conclusion, a low-cost, easy-purified, and effective producing strategy using the cheap raw materials was developed here, representing a potential application for protease production in various Industrial processes.
\end{abstract}

Keywords: Alkaline Protease; Bacillus; Enzyme Production; Raw Materials Based Strategy; Response Surface Methodology

"Corresponding author.

\section{INTRODUCTION}

Gram-positive bacteria of the genus Bacillus are widely appreciated as industrial workhorses for the production of various enzymes owing to their ability of secreting proteins into the extracellular medium [1]. Among the huge number of commercial enzymes, proteases are of great importance for their extensive applications in detergent, tanning, food processing, silk degumming, medical diagnosis, bioconversion, waste treatment, and peptide synthesis [2-5]. Currently, proteases have accounted for up to $60 \%$ of the total enzyme sales in the global market, in which alkaline proteases represent the largest portion [6].

The wide applications of alkaline proteases stimulate a considerable research interests in them. Biosynthesis of these enzymes is controlled by various regulation systems in microorganisms, such as quorum-sensing and two-component systems $[7,8]$. In this case cells can regulate gene expression and activation of proteins in response to a large variety of environmental signals including nutrients and cell density [9]. Therefore, the production of enzymes is strongly influenced by medium components, including $\mathrm{C} / \mathrm{N}$ ratio, easily metabolizable sugars, and nitrogen sources [10-14]. Besides, previous studies have shown that metabolizable carbon sources (such as glucose) and organic nitrogen sources, which are rich in amino acids and short peptides, display strong catabolite repression to protease production when used at higher concentrations $[12,15,16]$. Thus, development of a new strategy of evading catabolite repression to improve the alkaline protease production is of great necessity.

In the previous study, a strain Bacillus sp. B001 has been reported to produce a high level of extracellular protease about $34,277 \mathrm{U} / \mathrm{mL}$ and suggested its potential 
application in various industrial processes [17]. However, it is hard to further enhance the protease production by optimization of the available medium gradients of the original medium because the use of glucose, tryptone, and yeast extract causes catabolite repression on protease production [17]. To release the effect of catabolite repression and increase the protease production of Bacillus sp. B001, this study was proposed to develop a raw materials based (RMB) strategy using a statistical approach. Its potential applications for the protease purification and characterization and enzyme production by other Bacillus strains were further investigated.

\section{MATERIAL AND METHODS}

\subsection{Chemicals and Raw Materials}

All the chemicals used in present study were of the analytical grade. The azocasein was purchased from Sigma, USA. The hydrolyzed wheat gulten (HWG) was kindly donated by Wuhan Chortle Bio-chem Techonology Co., Ltd., China. Other cheap raw materials used in this study were obtained from Liangshan Ketai Biological Products Co., Ltd., Shandong, China, and Jining Fuqiang Materials Co., Ltd., Shandong, China.

\subsection{Bacterial Strains and Culture Conditions}

Bacillus sp. B001 was routinely grown on GYM medium comprising ingredients $(\mathrm{g} / \mathrm{L})$ : glucose 10.0 , tryptone 5.0 , yeast extract 5.0, $\mathrm{KH}_{2} \mathrm{PO}_{4} 1.0, \mathrm{MgSO}_{4} 0.2, \mathrm{Na}_{2} \mathrm{CO}_{3}$ 10.0, and agar 20.0 for solid medium [17]. B. subtilis W168, $B$. amyloliquefaciens TA208, were grown on LB medium (comprising ingredients $(\mathrm{g} / \mathrm{L})$ : peptone 10.0 , yeast extract 5.0, $\mathrm{NaCl} 10.0$, and agar 20.0 for solid medium). $B$. clausii DSM 8716 obtained from Deutsche Sammlung von Mikroorganismen und Zellkulturen (DSMZ) was grown on TSB medium (comprising ingredients $(\mathrm{g} / \mathrm{L})$ : peptone from casein 17, peptone from soymeal 3, glucose 2.5, $\mathrm{NaCl} 5, \mathrm{KH}_{2} \mathrm{PO}_{4} 2.5, \mathrm{MnSO}_{4} 1, \mathrm{MgCl}_{2} 1$, $\mathrm{NaHCO}_{3}$ 4.2, $\mathrm{Na}_{2} \mathrm{CO}_{3}$ 5.3, and agar 20.0 for solid medium) [18].

For seed culture, a loop of bacteria from the agar plate were transferred into a $250 \mathrm{~mL}$ Erlenmeyer flask containing $20 \mathrm{~mL}$ of the seed medium, and incubated at $30^{\circ} \mathrm{C}$ and $200 \mathrm{rpm}$ until the $\mathrm{OD}_{600}$ reached about 8.0. Unless specified otherwise, $1 \mathrm{~mL}$ of the seed culture was inoculated into $50 \mathrm{~mL}$ fermentation medium in a $500 \mathrm{~mL}$ Erlenmeyer flask. The compositions of fermentation medium were varied according to the experimental designs. Fermentation was performed at $34^{\circ} \mathrm{C}$ and $200 \mathrm{rpm}$. All of the experiments were carried out in triplicate.

\subsection{Screening Raw Carbon and Nitrogen Sources}

The effects of different raw carbon and nitrogen sources on protease production of B001 were evaluated by substituting the carbon (glucose) and nitrogen (yeast extract and tryptone) sources in the original GYM medium with different raw carbon (soluble starch, corn flour, and wheat bran) and nitrogen (cottonseed cake flour, soybean meal, soy peptone, and HWG) sources at different concentrations.

\subsection{Optimization of Medium Components by Experimental Design}

Three stages of statistical experimental designs were used to optimize medium components for high level of protease production by Bacillus sp. B001. The levels of factors and experimental design matrixes were performed as described before except for some modifications $[19,20]$. Firstly, a $2^{5-1}$ fractional factorial design (FFD) was employed to select the most important nutrients affecting protease production. Secondly, the method of steepest ascent was adopted to rapidly drive the variable concentrations from the initial estimate values to the proximity of the actual optimum values according to the regression coefficients obtained from the FFD. Finally, central composite design (CCD) of response surface methodology (RSM) was performed to investigate the optimal level of significant medium components affecting protease production.

\subsection{Protein Purification and SDS-PAGE Analysis}

The cell-free supernatant of fermentation cultures was collected and precipitated by $\left(\mathrm{NH}_{4}\right)_{2} \mathrm{SO}_{4}$ to $80 \%$ saturation, and the mixture was incubated overnight at $4{ }^{\circ} \mathrm{C}$. The precipitate was collected by centrifugation at 22,500 $\times \mathrm{g}$ for $30 \mathrm{~min}$, dissolved in TGN buffer $(50 \mathrm{mM}$ Tris-HCl, $50 \mathrm{mM} \mathrm{NaCl}, 5 \%$ glycerol, $\mathrm{pH}$ 8.0) and dialyzed against the same buffer to remove the residual ammonium sulfate at $4^{\circ} \mathrm{C}$. The crude extract was purified to be homogeneous through anion exchange DE52 chromatography (Whatman, England) with a linear gradient $(0-1 \mathrm{M})$ of $\mathrm{NaCl}$ in the same buffer and the active fractions were pooled and stored at $4^{\circ} \mathrm{C}$ for further analysis. Protein concentration was determined by the Coomassie Brilliant Blue dye method using bovine serumalbumin as a standard [21]. The cell-free supernatant, the crude mixture, and the purified protein were subjected to SDS-PAGE which was performed on a $5 \%$ stacking and a $12 \%$ resolving gel. The protein bands were visualized by staining with Coomassie brilliant blue R250.

\subsection{Protease Activity Assay}

Protease activity was measured using azocasein as substrate by a modified method of Deng et al. [17]. The 
absorbance at $440 \mathrm{~nm}$ was measured using the same reaction mixture with inactive enzyme as negative control. One unit activity was defined as the amount of enzyme that catalyzes the release of $1 \mu \mathrm{mol}$ azo-dye per minute.

\subsection{Effects of NaCl, Detergents, and Organic Solvents}

To determine the effects of $\mathrm{NaCl}$ and detergents on enzyme activity, the assay was carried out at standard conditions $(50 \mathrm{mM}$ Tris- $\mathrm{HCl}, 5 \mathrm{mM} \mathrm{CaCl} 2$, and $1 \%$ azocasein, $\mathrm{pH} 8.5)$ containing $0-4 \mathrm{M} \mathrm{NaCl}$ or $1 \%(\mathrm{w} / \mathrm{v})$ commercial available detergents. The endogenous proteases in the detergents were inactivated by boiling the diluted detergents for $30 \mathrm{~min}$ at $100^{\circ} \mathrm{C}$. The enzyme activity assayed in the absence of $\mathrm{NaCl}$ or detergent was taken as $100 \%$. To determine the effects of $\mathrm{NaCl}$, detergents, and organic solvents on enzyme stability, purified enzyme was incubated with 0 - $4 \mathrm{M} \mathrm{NaCl}, 1 \%$ detergents, or $50 \%$ solvents for $24 \mathrm{~h}$ at $20^{\circ} \mathrm{C}$ before the residual activity was measured. The enzyme activity assayed under the same condition without incubation with $\mathrm{NaCl}$, detergent, or solvent was set as $100 \%$.

\subsection{Statistical Analysis}

The Design-Expert version 8.0.6 software package (StatEase, Inc., Minneapolis, MN, USA) was used for the experimental designs, regression analysis of the experimental data, and plotting response surface graphs. Statistical analysis of the model was performed to evaluate the analysis of variance (ANOVA). The quality of the regression model was estimated by the coefficient of determination $R^{2}$, and its significance was determined by Fischer's test. The statistical significance of the regression coefficients was tested by Student's t-test. Finally, the optimum concentrations of the variables were calculated by differentiation of the quadratic equation [22]. All the experiments were carried out in triplicate.

\section{RESULTS AND DISCUSSION}

\subsection{Effects of Various Culture Conditions on the Protease Production}

The optimal $\mathrm{pH}$ and temperature for protease production were determined to be 11.0 , and $34^{\circ} \mathrm{C}$, respectively. Among different carbon sources tested (Figure 1), maximum enzyme yield of approximately 23,689 was achieved in corn flour, followed by glucose $(21,593 \mathrm{U} / \mathrm{mL})$, soluble starch $(18,570 \mathrm{U} / \mathrm{mL})$, and wheat bran $(2,185$ $\mathrm{U} / \mathrm{mL}$ ). Among various nitrogen sources, soy peptone was selected as the best suitable material favored alkaline protease production $(43,185 \mathrm{U} / \mathrm{mL})$. Similar enzyme yields were observed with soybean meal $(35,407 \mathrm{U} / \mathrm{mL})$

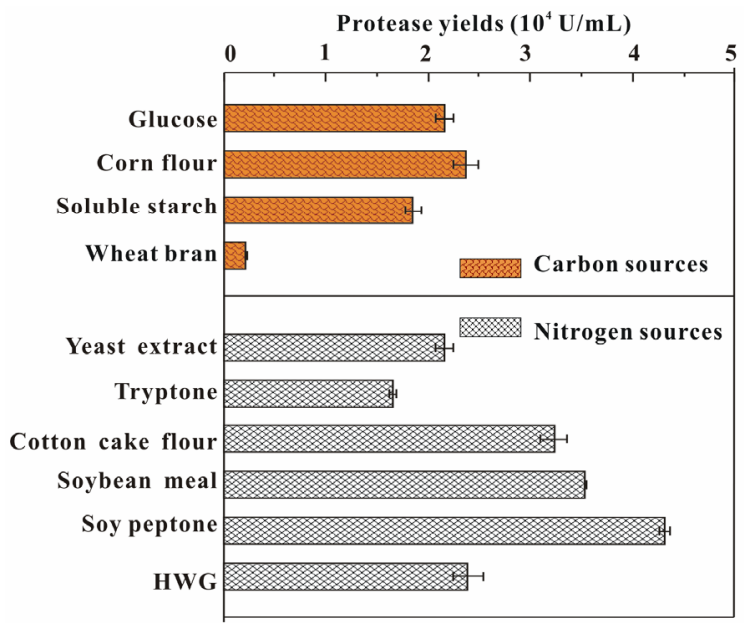

Figure 1. Effects of different carbon and nitrogen sources on the protease production by Bacillus sp. B001. Each carbon or nitrogen source was tested at different concentrations to get the maximum protease production.

and cotton cake flour $(32,311 \mathrm{U} / \mathrm{mL})$. While, lower enzyme yields were obtained when HWG $(23,919 \mathrm{U} / \mathrm{mL})$, yeast extract $(21,593 \mathrm{U} / \mathrm{mL})$, and tryptone $(16,622 \mathrm{U} / \mathrm{mL})$ were supplied as sole nitrogen source. Besides, $\mathrm{MgSO}_{4}$, $\mathrm{KH}_{2} \mathrm{PO}_{4}$, and $\mathrm{CaCl}_{2}$, which were added and optimized together in the flowing steps, could enhance the protease accumulation (data not shown). It has been shown that metabolizable carbon sources and organic nitrogen sources rich in amino acids and short peptides may repress enzyme production when higher concentrations were applied [12,15,23-25]. In order to relieve catabolite repression, Beg et al. [24] adopted an intermittent derepression and induction fed-batch strategy by separating biomass accumulation and protease production phases. In another case, citric acid was used to substitute glucose as the carbon source for alkaline protease production form B. licheniformis DSM 1969 [23]. In this study, we proposed to introduce a raw material based culture strategy on the basis that raw materials contained complex polymeric nutrients which were slowly hydrolyzed to metabolizable substrates by exoenzymes, thus high concentrations of which may be adopted without exerting catabolite repression. Therefore, corn flour and soy peptone were screened as suitable raw carbon and nitrogen sources enhancing proteases production of $\mathrm{B} 001$.

\subsection{Optimization of Medium Components by Experimental Design}

The most important medium components for the protease production were determined to be corn flour, soy peptone, and $\mathrm{KH}_{2} \mathrm{PO}_{4}$ by $2^{5-1}$ fractional factorial design (Tables 1 and 2). A modified first-order model equation fitted to the data (Table 2) was regressed to the equation below (Eq.1): 
Table 1. Applied levels of independent variables in the $2^{5-1}$ FFD.

\begin{tabular}{ccccc}
\hline \multirow{2}{*}{ Variable } & \multirow{2}{*}{ Component } & \multicolumn{3}{c}{ Levels of variables $(\mathrm{g} / \mathrm{L})$} \\
\cline { 3 - 5 } & & $-($ Low $)$ & 0 (Central) & $+($ High $)$ \\
\hline$X_{1}$ & Corn flour & 6.00 & 9.00 & 12.00 \\
$X_{2}$ & Soy peptone & 5.00 & 7.50 & 10.00 \\
$X_{3}$ & $\mathrm{MgSO}_{4}$ & 0.08 & 0.12 & 0.16 \\
$X_{4}$ & $\mathrm{KH}_{2} \mathrm{PO}_{4}$ & 0.80 & 1.20 & 1.60 \\
$X_{5}$ & $\mathrm{CaCl}_{2}$ & 0.40 & 0.60 & 0.80 \\
\hline
\end{tabular}

Table 2. $2^{5-1}$ FFD design matrix with corresponding results.

\begin{tabular}{|c|c|c|c|c|c|c|}
\hline \multirow{2}{*}{ Run } & \multicolumn{5}{|c|}{ Coded values } & \multirow{2}{*}{$\begin{array}{l}\text { Protease yields } \\
\quad(\mathrm{U} / \mathrm{mL})\end{array}$} \\
\hline & $X_{1}$ & $X_{2}$ & $X_{3}$ & $X_{4}$ & $X_{5}$ & \\
\hline 1 & + & + & - & + & - & 48207.41 \\
\hline 2 & - & - & + & - & - & 39244.44 \\
\hline 3 & + & - & - & - & - & 49792.59 \\
\hline 4 & - & - & + & + & + & 38444.44 \\
\hline 5 & + & - & - & + & + & 49392.59 \\
\hline 6 & + & + & - & - & + & 51688.89 \\
\hline 7 & - & - & - & - & + & 42192.59 \\
\hline 8 & + & - & + & + & - & 49555.56 \\
\hline 9 & + & - & + & - & + & 49511.11 \\
\hline 10 & + & + & + & + & + & 50755.56 \\
\hline 11 & - & + & - & + & + & 30755.56 \\
\hline 12 & - & + & - & - & - & 32637.04 \\
\hline 13 & - & + & + & + & - & 30311.11 \\
\hline 14 & - & + & + & - & + & 30029.63 \\
\hline 15 & + & + & + & - & - & 52725.93 \\
\hline 16 & - & - & - & + & - & 41644.44 \\
\hline 17 & 0 & 0 & 0 & 0 & 0 & 49925.93 \\
\hline 18 & 0 & 0 & 0 & 0 & 0 & 48844.44 \\
\hline 19 & 0 & 0 & 0 & 0 & 0 & 48414.81 \\
\hline 20 & 0 & 0 & 0 & 0 & 0 & 49407.41 \\
\hline 21 & 0 & 0 & 0 & 0 & 0 & 49659.26 \\
\hline
\end{tabular}

$$
\begin{aligned}
Y= & 42930.56+7273.15 x_{1}-2041.67 x_{2} \\
& -547.22 x_{4}+2682.41 x_{1} x_{2}+791.67 x_{1} x_{3}
\end{aligned}
$$

where $Y$ is the predicted enzyme production; $x_{1}, x_{2}, x_{3}$, and $x_{4}$ represent the coded values of corn flour, soy peptone, $\mathrm{MgSO}_{4}$, and $\mathrm{KH}_{2} \mathrm{PO}_{4}$, respectively. Then, the method of steepest ascent experiment was further carried out to move near to the optima of the three significant components, the maximum production of $61,800 \mathrm{U} / \mathrm{mL}$ was obtained at run 4 as shown in Table $3(16.20 \mathrm{~g} / \mathrm{L}$ corn flour, $5.85 \mathrm{~g} / \mathrm{L}$ soy peptone, and $1.13 \mathrm{~g} / \mathrm{L} \mathrm{KH}_{2} \mathrm{PO}_{4}$ ). Consequently, this medium was chosen for further RSM optimization.
Table 3. Experimental design and results of the steepest ascent path.

\begin{tabular}{ccccc}
\hline \multirow{2}{*}{ Run } & \multicolumn{3}{c}{ Coded (Real (g/L)) variables } & Protease yields \\
\cline { 2 - 4 } & $X_{1}$ & $X_{2}$ & $X_{4}$ & \\
\hline 1 & $0.00(9.00)$ & $0.00(7.50)$ & $0.00(1.20)$ & 50111.11 \\
2 & $0.80(11.40)$ & $-0.22(6.95)$ & $-0.06(1.18)$ & 56377.78 \\
3 & $1.60(13.80)$ & $-0.44(6.40)$ & $-0.12(1.15)$ & 59577.78 \\
4 & $2.40(16.20)$ & $-0.66(5.85)$ & $-0.18(1.13)$ & 61800.00 \\
5 & $3.20(18.60)$ & $-0.88(5.30)$ & $-0.24(1.10)$ & 60177.78 \\
6 & $4.00(21.00)$ & $-1.10(4.75)$ & $-0.30(1.08)$ & 57711.11 \\
\hline
\end{tabular}

According to the steepest ascent path results, a central composite design was performed to determine the optimal levels of the three important medium components. The coded and real values of variables at various levels are listed in Table 4. The experimental design and corresponding enzyme production of the central composite design were presented in Table 5. By applying multiple regression analysis on the experimental data (Table 5), a polynomial model was obtained as Eq.2:

$$
\begin{aligned}
Y= & 61821.89+1072.16 x_{1}+856.26 x_{2} \\
& +567.81 x_{4}+300 x_{1} x_{2}-683.33 x_{1} x_{4} \\
& -550 x_{2} x_{4}-725.53 x_{1}^{2}-1432.64 x_{2}^{2}-336.62 x_{4}^{2}
\end{aligned}
$$

where $Y$ is the predicted enzyme production; $x_{1}, x_{2}$, and $x_{4}$ is the coded values of corn flour, soy peptone, and $\mathrm{KH}_{2} \mathrm{PO}_{4}$, respectively. The model $F$-value of 59.69 with $P$-value less than 0.0001 indicated that the model was highly significant according to the analysis of variance. The results of ANONA for the full polynomial quadratic model were listed in Table 6. All terms in the model were statistically significant because their $P$-values were less than 0.05 , which demonstrated that corn flour, soy peptone, and $\mathrm{KH}_{2} \mathrm{PO}_{4}$, as well as their quadratic terms had significant effects on alkaline protease production. The fitness of the model was examined by the coefficient of determination $\mathrm{R}^{2}$, which was calculated to be 0.9817 , revealing a good correlation between the experimental and predicted values, i.e. above $98 \%$ of variability in the response could be explained by the established model. Therefore, the model is supposed to be adequate to predict the maximum levels of the variables and the corresponding response.

The 3D response surface were plotted to get a better description of the interactions between variables. As shown in Figure 2, each contour curve represented an infinitive number of combinations of two test variables with the other one held at the center point. The smallest ellipse in the contour diagram represented the maximum predicted values [26]. The interactions between corn flour and soy peptone, corn flour and $\mathrm{KH}_{2} \mathrm{PO}_{4}$, and soy peptone and $\mathrm{KH}_{2} \mathrm{PO}_{4}$ were depicted in Figure 2. All the 
Table 4. Coded and real values of variables in central composition design.

\begin{tabular}{cccccc}
\hline \multirow{2}{*}{ Variables } & \multicolumn{5}{c}{ Level of variables } \\
\cline { 2 - 6 } & $-1.682^{\mathrm{a}}$ & -1 & 0 & 1 & $1.682^{\mathrm{a}}$ \\
\hline$X_{1}$ Corn flour & 12.20 & 13.80 & 16.20 & 18.60 & 20.20 \\
$X_{2}$ Soy peptone & 4.93 & 5.30 & 5.85 & 6.40 & 6.80 \\
$X_{4} \mathrm{KH}_{2} \mathrm{PO}_{4}$ & 1.08 & 1.10 & 1.13 & 1.15 & 1.16 \\
\hline
\end{tabular}

${ }^{\mathrm{a}}$ The axial distance was chosen as 1.682 to make the design orthogonal. The low, middle, and high levels of each variable were designated as $-1.682,-1$, $0,+1$, and 1.682 , respectively. Other non-significant factors $\left(\mathrm{MgSO}_{4}, \mathrm{CaCl}_{2}\right)$ were set at the center point of the FFD. All the variables were coded as $x_{i}=\left(X_{i}-X_{c p}\right) / \Delta X_{i}, i=1,2, \cdots, k$, (where $x_{i}$ is the coded value of the independent variable; $X_{i}$ is the real value; $X_{c p}$ is the value of $X_{i}$ at the center point; $\Delta X_{i}$ is the step change of real value).

Table 5. Experimental design and results of central composite design.

\begin{tabular}{|c|c|c|c|c|}
\hline \multirow{2}{*}{ Run } & \multicolumn{3}{|c|}{ Factor variables (coded level) } & \multirow{2}{*}{$\begin{array}{l}\text { Protease yields } \\
\quad(\mathrm{U} / \mathrm{mL})\end{array}$} \\
\hline & $X_{1}$ & $X_{2}$ & $X_{4}$ & \\
\hline $1^{\mathrm{a}}$ & -1 & -1 & -1 & 55733.33 \\
\hline $2^{\mathrm{a}}$ & +1 & -1 & -1 & 59066.67 \\
\hline $3^{\mathrm{a}}$ & -1 & +1 & -1 & 57866.67 \\
\hline $4^{\mathrm{a}}$ & +1 & +1 & -1 & 62233.30 \\
\hline $5^{\mathrm{a}}$ & -1 & -1 & +1 & 59633.33 \\
\hline $6^{\mathrm{a}}$ & +1 & -1 & +1 & 60066.67 \\
\hline $7^{\mathrm{a}}$ & -1 & +1 & +1 & 59400.00 \\
\hline $8^{\mathrm{a}}$ & +1 & +1 & +1 & 61200.00 \\
\hline $9^{\mathrm{b}}$ & -1.682 & 0 & 0 & 58266.67 \\
\hline $10^{\mathrm{b}}$ & +1.682 & 0 & 0 & 61066.67 \\
\hline $11^{\mathrm{b}}$ & 0 & -1.682 & 0 & 56033.33 \\
\hline $12^{\mathrm{b}}$ & 0 & +1.682 & 0 & 59300.00 \\
\hline $13^{\mathrm{b}}$ & 0 & 0 & -1.682 & 60066.67 \\
\hline $14^{\mathrm{b}}$ & 0 & 0 & +1.682 & 61466.67 \\
\hline $15^{\mathrm{c}}$ & 0 & 0 & 0 & 61600.00 \\
\hline $16^{\mathrm{c}}$ & 0 & 0 & 0 & 61866.70 \\
\hline $17^{\mathrm{c}}$ & 0 & 0 & 0 & 61733.33 \\
\hline $18^{\mathrm{c}}$ & 0 & 0 & 0 & 61666.67 \\
\hline $19^{c}$ & 0 & 0 & 0 & 62300.00 \\
\hline $20^{\mathrm{c}}$ & 0 & 0 & 0 & 61800.00 \\
\hline
\end{tabular}

a 23 factorial design was used to fit the first-order model; ${ }^{\mathrm{b}} \mathrm{Six}$ axial points were employed to make the quadratic polynomial can be added to the first-order model; " $\mathrm{Six}$ replications of the center points were used to estimate the experimental error and to check the adequacy of the model.

contour plots showed in Figure 2 were elliptical, demonstrating perfect interactions between the three independent variables [27], which was in well agreement with their low $P$-values obtained in previous statistical analysis (Table 6).

The optimum concentrations of the variables were calculated by solving the regression equation Eq.2. The optimal values of each test component in coded units were as follows: $x_{1}=1.403, x_{2}=0.661, x_{4}=-1.121$. Thus, the actual concentration of corn flour, soy peptone and $\mathrm{KH}_{2} \mathrm{PO}_{4}$ were $19.60,6.20$, and $1.16 \mathrm{~g} / \mathrm{L}$, respectively.

\subsection{Enhanced Protease Production of Strain B001 in Optimized Medium}

Three validation experiments were performed to verify the accuracy of the model by using statistical optimized medium: corn flour $19.60 \mathrm{~g} / \mathrm{L}$, soy peptone $6.20 \mathrm{~g} / \mathrm{L}$, $\mathrm{KH}_{2} \mathrm{PO}_{4} 1.16 \mathrm{~g} / \mathrm{L}, \mathrm{MgSO}_{4} 0.12 \mathrm{~g} / \mathrm{L}, \mathrm{CaCl}_{2} 0.60 \mathrm{~g} / \mathrm{L}$, and $\mathrm{Na}_{2} \mathrm{CO}_{3} 10.0 \mathrm{~g} / \mathrm{L}$. An enzyme production of $63,200 \mathrm{U} / \mathrm{mL}$ was obtained at the fermentation time of $27 \mathrm{~h}$ (Figure 3(a)), which was in agreement with the predicted maximum value of 62,539 U/mL calculated according to Eq.2. As shown in Figure 3(a), the increase of protease production correlated with the biomass accumulation for 24 $h$. The cells then entered into the stationary phase and the maximum enzyme production of $63,200 \mathrm{U} / \mathrm{mL}$ was reached at $27 \mathrm{~h}$. After that time, the enzyme yields were relatively stable despite the decrease in biomass.

The protease production showed three improvements compared with the previous condition [17]: 1) the protease production of Bacillus sp. B001 was 1.84 folds higher than the previous value, 2) the fermentation time for maximum protease production was three hours earlier than the previous conditions, and 3) a relatively stable enzyme production was observed in the stationary and declining phases in the optimized medium which is of great significance in industrial fermentation, because this improvement makes the enzyme harvest time wider. These improvements could be attributed to the slow release of available nutrients into the medium though hydrolyzing corn flour and soy peptone by the enzymes secreted by Bacillus sp. B001, preventing the repressive effects of high concentration of catabolites. In addition, the utilization of corn flour and soy peptone as economical raw materials in fermentation decreases the production costs. Taken together, these results have shown that the optimized fermentation medium could sustain a stable, high yield of protease produced by Bacillus sp. B001 over a longer period of fermentation. To the best of our knowledge, the protease yield achieved in the optimized medium is much higher than the results obtained by previous shake-flask fermentation $[10,17$, $28,29]$. Besides, the cost of medium was cut down by using inexpensive raw materials which is of great importance, because the cost of medium is one of the major obstacles against the successful application of any tech- 
Table 6. Analysis of variance of the full second-order quadratic model.

\begin{tabular}{|c|c|c|c|c|c|}
\hline Source & SS & DF & MS & $F$-Value $^{\mathrm{a}}$ & $P$-value (Prob. $>\mathrm{F}$ ) \\
\hline Model & 71815330 & 9 & 9905284 & 59.69 & $<0.0001^{*}$ \\
\hline$X_{1}$ & 15698896 & 1 & 16395268 & 117.44 & $<0.0001^{*}$ \\
\hline$X_{2}$ & 10012958 & 1 & 14513562 & 74.90 & $<0.0001^{*}$ \\
\hline$X_{4}$ & 4403133 & 1 & 953764.8 & 32.94 & $0.0002^{*}$ \\
\hline$X_{1} X_{2}$ & 719980 & 1 & 200555.6 & 5.39 & $0.0427^{*}$ \\
\hline$X_{1} X_{4}$ & 3735510 & 1 & 5667222 & 27.94 & $0.0004^{*}$ \\
\hline$X_{2} X_{4}$ & 2419963 & 1 & 4400556 & 18.10 & $0.0017^{*}$ \\
\hline$X_{1}^{2}$ & 7586071 & 1 & 6191073 & 56.75 & $<0.0001^{*}$ \\
\hline$X_{2}^{2}$ & 29578539 & 1 & 43614988 & 221.26 & $<0.0001^{*}$ \\
\hline$X_{4}^{2}$ & 1633026 & 1 & 850684.5 & 12.24 & $0.0058^{*}$ \\
\hline Residual & 1336812 & 10 & 133681.2 & & \\
\hline Lack of fit & 1024773 & 5 & 204954.6 & $3.28^{\mathrm{b}}$ & $0.1089^{* *}$ \\
\hline Pure error & 312039.6 & 5 & 62407.9 & & \\
\hline Cor total & 73152142 & 19 & & & \\
\hline Std. dev. & 365.62 & $R$-Squared & 0.981726 & & \\
\hline Mean & 60118.33 & Adj $R$-Squared & 0.965279 & & \\
\hline C.V.\% & 0.61 & Pred $R$-Squared & 0.887214 & & \\
\hline Press & 8250556 & Adeq Precision & 24.45888 & & \\
\hline
\end{tabular}

$\mathrm{SS}$, sum of squares; DF, degrees of freedom; MS, mean square. ${ }^{*}$ Significant at $P \leq 0.05,{ }^{* *}$ none significant. ${ }^{\text {a }}$ The Model $F$-value of 59.69 with $P$-value less than 0.0001 indicates that the model is highly significant. There is only a $0.01 \%$ chance that a "Model $F$-Value" this large could occur due to noise. Values of "Prob $>F^{\prime}$ less than 0.0500 indicate model terms are significant. In this case, all terms are significant; ${ }^{\text {b }}$ The model lack of fit $F$-value of 3.82 with $P$-value $=0.1089$ implies that the lack of fit is not significant relative to the pure error and there is a $10.89 \%$ chance that a lack of fit $F$-value this large could occur due to noise. "Adeq Precision" measures the signal to noise ratio. A ratio greater than 4 is desirable. The ratio of 24.45888 indicates an adequate signal. This model can be used to navigate the design space.
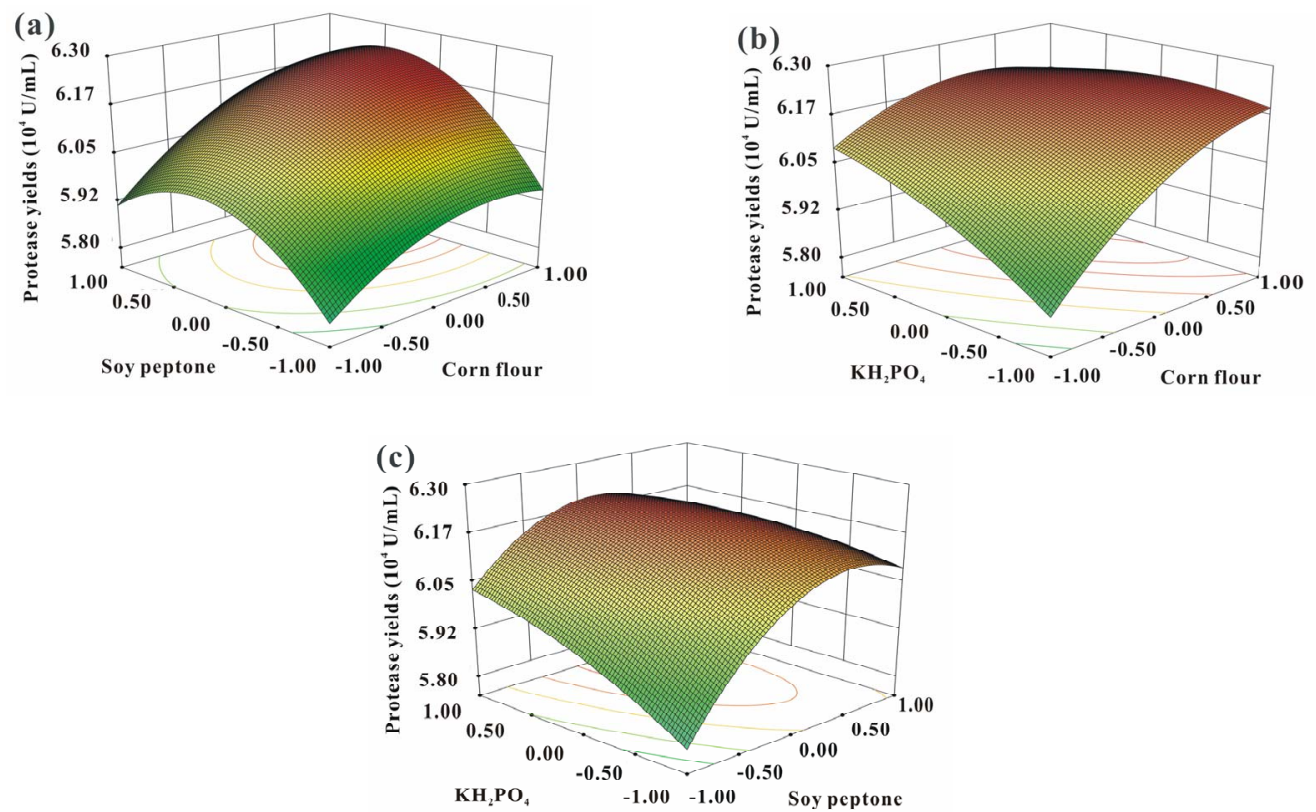

Figure 2. 3D response surfaces and corresponding contour plots indicating the mutual effects between soy peptone and corn flour (a), $\mathrm{KH}_{2} \mathrm{PO}_{4}$ and corn flour (b), and $\mathrm{KH}_{2} \mathrm{PO}_{4}$ and soy peptone on protease production (c). 


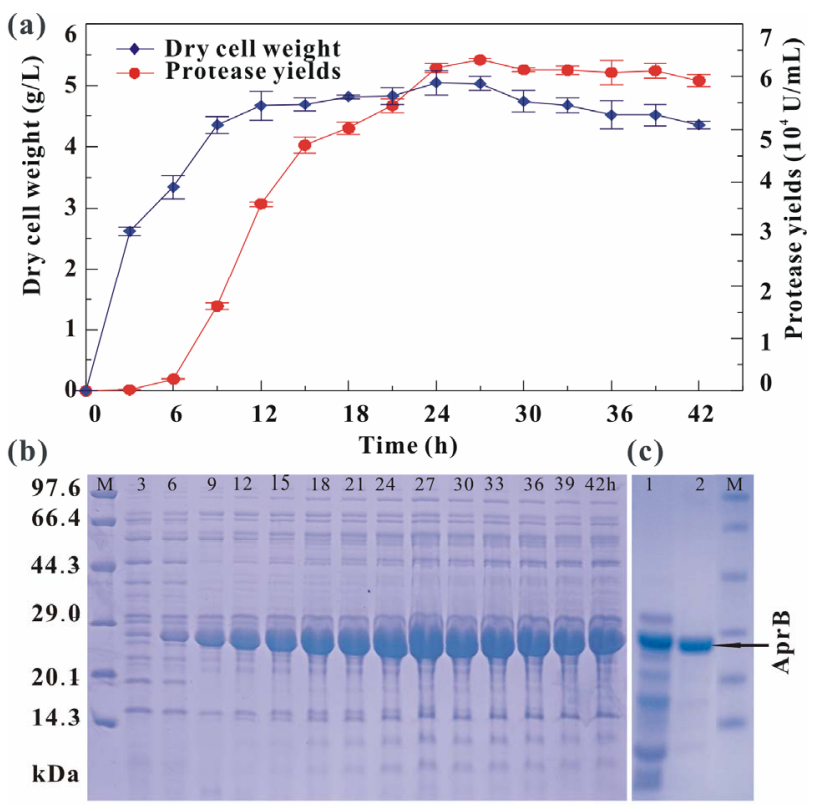

Figure 3. Time course of the protease production (a) and SDSPAGE analysis of the extracellular (b) and purified (c) proteases from B001 under optimized condition. Lane M, protein marker; Lanes 3 to 42 , the total proteins from cell-free supernatants for each $3 \mathrm{~h}$ interval. Lane 1 , crude proteins precipitated by $\left(\mathrm{NH}_{4}\right)_{2} \mathrm{SO}_{4}$; Lane 2, protein purified by anion exchange.

nology in the enzyme industry [2,11].

\subsection{Purification of Extracellular Protease}

The protease in the fermentation supernatant was also characterized by SDS-PAGE (Figure 3(b)). The majority of extracelluar proteins were near to a molecular weight of approximately $27 \mathrm{kDa}$, the amount of which varied in accordance with protease activity at different stages of growth (Figure 3(a)). The protease yield and purification fold of $23.6 \%$ and 3.8 , respectively, were obtained by ammonium sulphate fractionation followed by anion exchanger (Table 7). Protein purification was successfully achieved to the homogeneity as evident by a single band corresponding to $27 \mathrm{kDa}$ on SDS-PAGE (Figure 3(c)). Compared with the previous study in which the extracelluar protease yield of B001 was 5.6\% [17], the purification procedure in this study not only achieves a higher yield, but also an easier process. Therefore, extracellular protease produced in the optimized culture accounted for the majority of extracellular proteins and would make the following purification process much easier.

\subsection{Effects of Salt and Detergents on Protease Activity and Stability}

The purified protease remained active and stable with most of the compounds tested (Figures 4(a) and (b)). In the presence of $1 \mathrm{M} \mathrm{NaCl}$, the enzyme retained $72.5 \%$ of relative activity. A rapid decrease was observed with 2 and $4 \mathrm{M} \mathrm{NaCl}$. However, the enzyme retained above $100 \%$ residual activity after incubation with $1-4 \mathrm{M}$ $\mathrm{NaCl}$ for $24 \mathrm{~h}$. The effects of $\mathrm{NaCl}$ on the protease activity were similar with that on rSAPB activity; however, its salt-stability was higher than rSAPB and similar with the triple mutated SAPB-L31I/T33S/N99Y [30]. Therefore, the extracellular protease from B001 displays high salt-stability making enzyme keep stable during the granulation process of detergents formation.

As shown in Figure 4(b), purified protease from B001 showed relative high activity and stability in the presence of commercial laundry detergents. It exhibited more than $100 \%$ activities in the presence of Keon and Ariel, followed by Cnice $(75.3 \%)$, Tide $(69.4 \%)$, and OMO $(37.8 \%)$. After incubated with various detergents for $1 \mathrm{~h}$, the enzyme also retained more than $100 \%$ activity in Tide and Ariel, and displayed 96.4\%, 89.8\%, and 66.9\% activities when exposed to Cnice, Keon, and OMO, respectively. The highly stability towards salt and good compatibility with commercial laundry detergents of protease from B001 gives strong support for its application as detergent additives.

\subsection{Effects of Organic Solvents on Protease Stability}

To determine the effects of solvents on protease stability, Butanol $(\log P=0.88)$, Hexamethylene $(\log P=3.2)$, N-hexane $(\log P=3.5)$, DMSO $(\log P=-1.35)$, Acetonitrile $(\log P=-0.15)$, Methanol $(\log P=-0.76)$, Ethanol $(\log P=-0.24)$, Isopropanol $(\log P=0.05)$, Xylene $(\log P$ $=3.1)$, Benzene $(\log P=2.0)$, and Acetone $(\log P=0.2)$ at concentration of $50 \%(\mathrm{v} / \mathrm{v})$ were selected. As shown in Figure 4(c), the enzyme retained more than $100 \%$ activity in various tested solvents with $\log P<4.0$. It is well known that the solvent with $\log P<4.0$ is considered to be extremely toxic because of their higher degree of partitioning into the aqueous layer which disrupts the hydrogen bonding and hydrophobic interactions and results in loss of enzyme activity [31]. However, solventstable enzymes usually contain a greater number of negatively charged acidic amino acids on the surface which keep the protein soluble either by preventing the protein aggregation via electrostatic repulsion or by forming hydrated ion networks with cations [32]. Therefore, the excellent tolerance to solvent of the protease from Bacillus sp. B001 might be attributed to its high ratio of negative charged amino acids which accounts for $21.24 \%$ surface [33]. This remarkable property substantiates promising application of enzyme as a biocatalyst for peptide synthesis in low water systems. 
Table 7. Purification of extracellular protease from Bacillus sp. B001.

\begin{tabular}{cccccc}
\hline Purification step & Total activity $\left(\times 10^{5} \mathrm{U}\right)$ & Total protein & Specific activity $\left(\times 10^{3} \mathrm{U} / \mathrm{mg}\right)$ & Yield $(\%)$ & Purification fold \\
\hline Culture supernatant & 619 & 2481.8 & 24.9 & 100 & 1 \\
$\left(\mathrm{NH}_{4}\right)_{2} \mathrm{SO}_{4}$ precipitation & 180 & 378.5 & 47.6 & 29.1 & 1.9 \\
Anion exchange & 146 & 163.9 & 89.1 & 23.6 & 3.8 \\
\hline
\end{tabular}
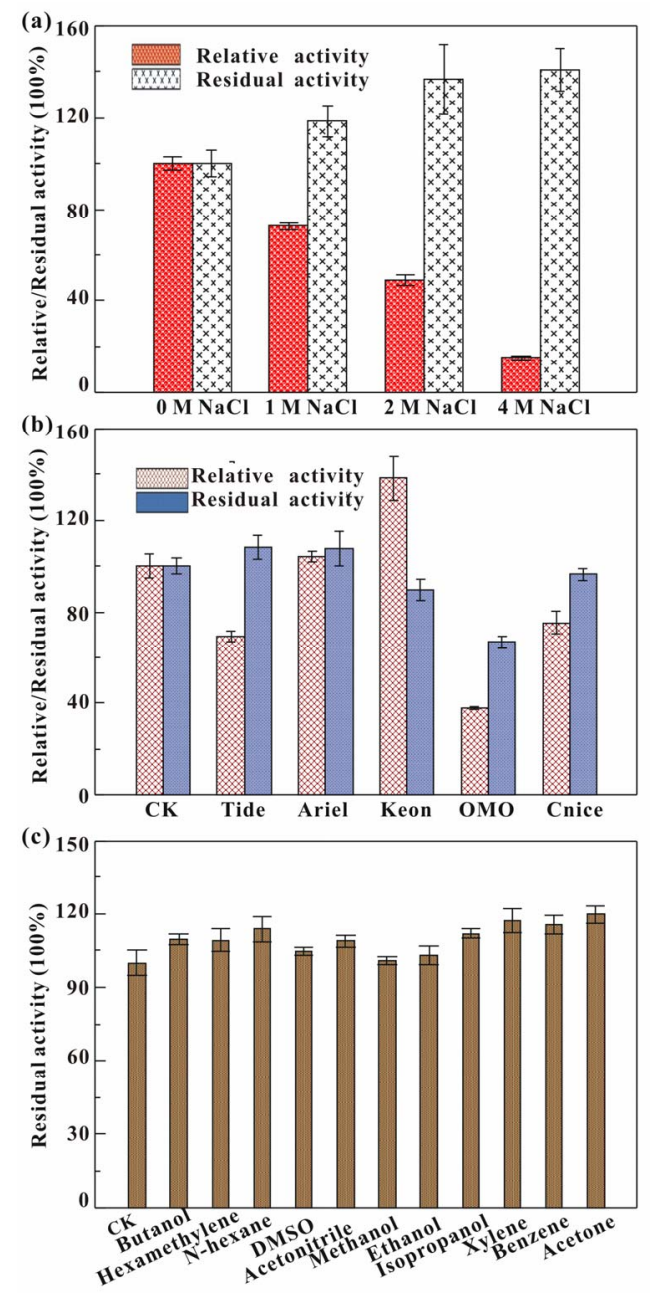

Figure 4. Effects of salt (a), commercial detergents (b), and organic solvents (c) on protease.

\subsection{Effects of Medium on the Extracelluar Protease Production of Other Bacillus Strains}

The raw material based culture strategy was also applied for producing protease by other Bacillus strains using the optimized medium. As shown in Figure 5, the culture strategy significantly enhanced extracelluar protease production of $B$. subtilis, B. amyloliquefaciens, and $B$. clausii by $2.9,8.5$, and 3.2 times, respectively. The effective application of the culture strategy in Bacillus strains could be attributed to the effect of the crude materials corn flour and soy peptone on the release of the catabolite

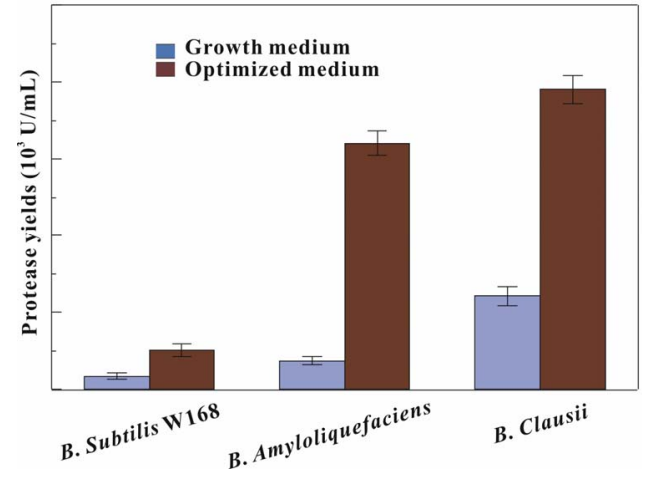

Figure 5. The extracellular proteases production of Bacillus strains with raw material based culture strategy.

repression common in all bacteria stains. Therefore, the raw material based culture strategy, which displayed promising advances in effectively enhancing the exoenzyme yield and cutting down the medium cost, is an effectively method that might be wildly applied in the enzyme production in various Bacillus strains, even in other genus.

\section{CONCLUSION}

In this study, a raw material based culture strategy was developed to increase the protease production by Bacillus strains. Cheap corn flour and soy peptone were screened as the optimum raw materials and optimized by statistical experiment designs. Under the optimized conditions, the protease productions of Bacillus sp. B001 and other Bacillus strains were significantly increased 1.8 - 8.4 folds. Additionally, protease from the optimized fermentation cultures of B001 was quickly purified to homogeneity by ammonium sulphate precipitation and anion exchange. The purified enzyme exhibits superior tolerant to high salt, commercial laundry detergents, and a wide range of organic solvents. Taken together, a lowcost, easy-purified, and effective producing strategy was developed in this study, which represented a potential application for enzyme production by various bacteria strains.

\section{ACKNOWLEDGEMENTS}

Financial supports from the National Hi-Tech Research and Development of China (2007AA02Z212) and the Key Project of Chinese Academy of Sciences (KSCX2-YW-G-075-22) were gratefully ack- 
nowledged.

\section{REFERENCES}

[1] Zeigler, D.R., Prágai, Z., Rodriguez, S., Chevreux, B., Muffler, A., Albert, T., Bai, R., Wyss, M. and Perkins, J.B. (2008) The origins of 168, W23, and other Bacillus subtilis legacy strains. Journal of Bacteriology, 190, 69836995. http://dx.doi.org/10.1128/JB.00722-08

[2] Gupta, R., Beg, Q.K. and Lorenz, P. (2002) Bacterial alkaline proteases: Molecular approaches and industrial applications. Applied Microbiology and Biotechnology, 59, 15-32. http://dx.doi.org/10.1007/s00253-002-0975-y

[3] Ahuja, S.K., Ferreira, G.M. and Moreira, A.R. (2004) Utilization of enzymes for environmental applications. Critical Reviews in Biotechnology, 24, 125-154. http://dx.doi.org/10.1080/07388550490493726

[4] Maurer, K.H. (2004) Detergent proteases. Current Opinion in Biotechnology, 15, 330-334. http://dx.doi.org/10.1016/j.copbio.2004.06.005

[5] Qin, X., Khuong, A.C., Yu, Z., Du, W., Decatur, J. and Gross, R.A. (2013) Simplifying alternating peptide synthesis by protease-catalyzed dipeptide oligomerization. Chemical Communications, 49, 385-387. http://dx.doi.org/10.1039/c2cc36381j

[6] Reddy, L.V., Wee, Y.J., Yun, J.S. and Ryu, H.W. (2008) Optimization of alkaline protease production by batch culture of Bacillus sp. RKY3 through Plackett-Burman and response surface methodological approaches. Bioresource Technology, 99, 2242-2249.

http://dx.doi.org/10.1016/j.biortech.2007.05.006

[7] Perchat, S., Dubois, T., Zouhir, S., Gominet, M., Poncet, S., Lemy, C., Nicaise, M.A., Deutscher, J., Gohar, M., Nessler, S., et al. (2011) A cell-cell communication system regulates protease production during sporulation in bacteria of the Bacillus cereus group. Molecular Microbiology, 82, 619-633.

http://dx.doi.org/10.1111/j.1365-2958.2011.07839.x

[8] Trip, H., van der Veek, P.J., Renniers, T.C., Meima, R., Sagt, C.M., Mohrmann, L. and Kuipers, O.P. (2011) A novel screening system for secretion of heterologous proteins in Bacillus subtilis. Microbial Biotechnology, 4, 673-682.

http://dx.doi.org/10.1111/j.1751-7915.2011.00270.x

[9] Gorke, B. and Stulke, J. (2008) Carbon catabolite repression in bacteria: Many ways to make the most out of nutrients. Nature Reviews Microbiology, 6, 613-624. http://dx.doi.org/10.1038/nrmicro1932

[10] Chauhan, B. and Gupta, R. (2004) Application of statistical experimental design for optimization of alkaline protease production from Bacillus sp. RGR-14. Process Biochemistry, 39, 2115-2122. http://dx.doi.org/10.1016/j.procbio.2003.11.002

[11] Haddar, A., Zouari, N.F., Hmidet, N., Frikha, F., Nasri, M. and Kamoun, A.S. (2010) Low-cost fermentation medium for alkaline protease production by Bacillus mojavensis A21 using hulled grain of wheat and sardinella peptone. Journal of Bioscience and Bioengineering, 110, 288-294. http://dx.doi.org/10.1016/j.jbiosc.2010.03.015
[12] Joo, H.S., Kumar, C.G., Park, G.C., Paik, S.R. and Chang, C.S. (2004) Bleach-resistant alkaline protease produced by a Bacillus sp. isolated from the Korean polychaete, Periserrula leucophryna. Process Biochemistry, 39, 14411447. http://dx.doi.org/10.1016/S0032-9592(03)00260-7

[13] Beg, Q.K., Sahai, V. and Gupta, R. (2003) Statistical media optimization and alkaline protease production from Bacillus mojavensis in a bioreactor. Process Biochemistry, 39, 203-209. http://dx.doi.org/10.1016/S0032-9592(03)00064-5

[14] Kumar, C.G. and Takagi, H. (1999) Microbial alkaline proteases: From a bioindustrial viewpoint. Biotechnology Advances, 17, 561-594.

http://dx.doi.org/10.1016/S0734-9750(99)00027-0

[15] Patel, R., Dodia, M. and Singh, S.P. (2005) Extracellular alkaline protease from a newly isolated haloalkaliphilic Bacillus sp.: Production and optimization. Process Biochemistry, 40, 3569-3575. http://dx.doi.org/10.1016/j.procbio.2005.03.049

[16] Meyer, F.M., Jules, M., Mehne, F.M.P., Le Coq, D., Landmann, J.J., Görke, B., Aymerich, S. and Stülke, J. (2011) Malate-Mediated Carbon Catabolite Repression in Bacillus subtilis Involves the HPrK/CcpA Pathway. Journal of Bacteriology, 193, 6939-6949. http://dx.doi.org/10.1128/JB.06197-11

[17] Deng, A., Wu, J., Zhang, Y., Zhang, G. and Wen, T. (2010) Purification and characterization of a surfactantstable high-alkaline protease from Bacillus sp. B001. Bioresource Technology, 101, 7100-7106. http://dx.doi.org/10.1016/j.biortech.2010.03.130

[18] Nielsen, P., Fritze, D. and Priest, F.G. (1995) Phenetic diversity of alkaliphilic Bacillus strains: Proposal for nine new species. Microbiology, 141, 1745-1761. http://dx.doi.org/10.1099/13500872-141-7-1745

[19] Su, J.-J., Zhou, Q., Zhang, H.-Y., Li, Y.-Q., Huang, X.-Q. and $\mathrm{Xu}, \mathrm{Y} . \mathrm{Q}$. (2010) Medium optimization for phenazine1-carboxylic acid production by a gacA qscR double mutant of Pseudomonas sp. M18 using response surface methodology. Bioresource Technology, 101, 4089-4095. http://dx.doi.org/10.1016/j.biortech.2009.12.143

[20] Jafari, R., Sundstrom, B.E. and Holm, P. (2011) Optimization of production of the anti-keratin 8 single-chain Fv TS1-218 in Pichia pastoris using design of experiments. Microbial Cell Factories, 10, 34. http://dx.doi.org/10.1186/1475-2859-10-34

[21] Bradford, M.M. (1976) A rapid and sensitive method for the quantitation of microgram quantities of protein utilizing the principle of protein-dye binding. Analytical Biochemistry, 72, 248-254.

http://dx.doi.org/10.1016/0003-2697(76)90527-3

[22] Gao, H., Liu, M., Liu, J., Dai, H., Zhou, X., Liu, X., Zhuo, Y., Zhang, W. and Zhang, L. (2009) Medium optimization for the production of avermectin B1a by Streptomyces avermitilis 14-12A using response surface methodology. Bioresource Technology, 100, 4012-4016. http://dx.doi.org/10.1016/j.biortech.2009.03.013

[23] Çalík, P., Çalík, G. and Özdamar, T.H. (1998) Oxygen transfer effects in serine alkaline protease fermentation by Bacillus licheniformis: Use of citric acid as the carbon 
source. Enzyme and Microbial Technology, 23, 451-461. http://dx.doi.org/10.1016/S0141-0229(98)00069-6

[24] Beg, Q.K., Saxena, R.K. and Gupta, R. (2002) De-repression and subsequent induction of protease synthesis by Bacillus mojavensis under fed-batch operations. Process Biochemistry, 37, 1103-1109. http://dx.doi.org/10.1016/S0032-9592(01)00320-X

[25] Mehta, V.J., Thumar, J.T. and Singh, S.P. (2006) Production of alkaline protease from an alkaliphilic actinomycete. Bioresource Technology, 97, 1650-1654. http://dx.doi.org/10.1016/j.biortech.2005.07.023

[26] Tanyildizi, M.S., Özer, D. and Elibol, M. (2005) Optimization of $\alpha$-amylase production by Bacillus sp. using response surface methodology. Process Biochemistry, 40, 2291-2296. http://dx.doi.org/10.1016/j.procbio.2004.06.018

[27] Guo, W.-Q., Ren, N.-Q., Wang, X.-J., Xiang, W.-S., Ding, J., You, Y. and Liu, B.-F. (2009) Optimization of culture conditions for hydrogen production by Ethanoligenens harbinense B49 using response surface methodology. Bioresource Technology, 100, 1192-1196. http://dx.doi.org/10.1016/j.biortech.2008.07.070

[28] Joo, H.S. and Chang, C.S. (2005) Oxidant and SDS-stable alkaline protease from a halo-tolerant Bacillus clausii I-52: Enhanced production and simple purification. Journal of Applied Microbiology, 98, 491-497. http://dx.doi.org/10.1111/j.1365-2672.2004.02464.x

[29] Hajji, M., Rebai, A., Gharsallah, N. and Nasri, M. (2008) Optimization of alkaline protease production by Asper- gillus clavatus ES1 in Mirabilis jalapa tuber powder using statistical experimental design. Applied Microbiology and Biotechnology, 79, 915-923. http://dx.doi.org/10.1007/s00253-008-1508-0

[30] Zaraî Jaouadi, N., Jaouadi, B., Aghajari, N. and Bejar, S. (2012) The overexpression of the SAPB of Bacillus pumilus CBS and mutated sapB-L31I/T33S/N99Y alkaline proteases in Bacillus subtilis DB430: New attractive properties for the mutant enzyme. Bioresource Technology, 105, 142-151. http://dx.doi.org/10.1016/j.biortech.2011.11.115

[31] Raut, G., Vetal, S., Biao, R., Liu, X.-Y., Zhang, L. and Kokare, C. (2012) Purification and characterization of organic solvent and detergent stable protease isolated from marine Saccharopolyspora sp. A9: Application of protease for wound healing. Biochemical Engineering Journal, 69, 196-203. http://dx.doi.org/10.1016/j.bej.2012.09.002

[32] Jain, D., Pancha, I., Mishra, S.K., Shrivastav, A. and Mishra, S. (2012) Purification and characterization of haloalkaline thermoactive, solvent stable and SDS-induced protease from Bacillus sp.: A potential additive for laundry detergents. Bioresource Technology, 115, 228-236. http://dx.doi.org/10.1016/j.biortech.2011.10.081

[33] Deng, A., Wu, J., Zhang, G. and Wen, T. (2011) Molecular and structural characterization of a surfactant-stable high-alkaline protease AprB with a novel structural feature unique to subtilisin family. Biochimie, 93, 783-791. http://dx.doi.org/10.1016/j.biochi.2011.01.011 